p. 79) is but a branched species (I should have stated "variety") of Squamulina scopula.

I have just now found several specimens of the branched form of Squamulina scopula on the rocks here (Budleigh-Salterton, Devon), growing among sponges \&c. far above low-water mark, so that they are uncovered there twice every day for two or three hours at a time.

It is generally dichotomous, but by no means always so. The most perfect and largest specimen I have has eight heads. Its total length is about $2 \frac{1}{2}$ twelfths of an inch, the stem before branching being $1 \frac{1}{2}$, and the branched portion 1 line long by $1 \frac{1}{2}$ line broad in the spread. Thus it has undergone division three times.

On cutting off the branched head with a pair of scissors across the main stem, and placing it in a watch-glass of sea-water (into which the specimen had been put on the piece of rock on which it grew, immediately on being broken off), the truncated end soon after threw out a bunch of obliquely branching and anastomosing filaments or pseudopodia, to the extent of 1-60th of an inch long, all round, which continued retracting and extending themselves and exhibiting the granule-circulation, after the manner of the sareode of the Foraminifera, for six hours, when the whole were gradually withdrawn and did not reappear.

Thus the foraminiferous character of Squamulina scopula and its branched variety (which is precisely like it, with the exception of the branching) is proved.

I could not see any filaments projected from the heads in any of the specimens; nor would it be easy to do so, as these probably entwine themselves about the spicules which are always raised up from the bottom in the water; but the truncated end of the stem lay on the watch-glass, over which it was easy to see the extended filaments with a one-inch compound power.

Specimens, of course, which grow on the rocks, exposed to all the fury of the waves, are not so perfect in their spicular element as those which grow in deep and more or less still water. But the wonder is how such delicate little creatures can grow at all in such turbulent situations.

\title{
On two Species of Land-Planariæ from Borneo.
}

\section{To the Editors of the Annals and Magazine of Natural History.}

Gentlemen,-The figures and descriptions of the Turbellarians given by the Rev. W. Houghton in your last Number point them out as belonging to the genus Bipalium of Stimpson (Sphyrocephalus of Schmarda and Dunlopea of E. P. Wright in a former Number of the Annals). They are rather common forms in tropical regions. An account of their structure has been published by Schmarda, and also by M. Claparède. Their anatomy has been investigated by the writer in relation to their homologies with the Nemerteans.

September 23, 1870. I am, yours, \&c.,

W. C. M·Ivтовн. 


\section{$2 \mathrm{BHL}$ Biodiversity Heritage Library}

1870. "On two species of land-Planariæ from Borneo." The Annals and magazine of natural history; zoology, botany, and geology 6, 347-347. https://doi.org/10.1080/00222937008696264.

View This Item Online: https://www.biodiversitylibrary.org/item/93156

DOI: https://doi.org/10.1080/00222937008696264

Permalink: https://www.biodiversitylibrary.org/partpdf/68000

\section{Holding Institution}

Missouri Botanical Garden, Peter H. Raven Library

\section{Sponsored by}

Missouri Botanical Garden

\section{Copyright \& Reuse}

Copyright Status: Public domain. The BHL considers that this work is no longer under copyright protection.

This document was created from content at the Biodiversity Heritage Library, the world's largest open access digital library for biodiversity literature and archives. Visit BHL at https://www.biodiversitylibrary.org. 